Одсек за српску књижевност

(докторанд)

\title{
КЊИЖЕВНИ ОТПОР КАО КУЛТУРНИ ФЕНОМЕН
}

\begin{abstract}
У раду се осветљава феномен отпора у књижевности, указује се на природу неразлучиве корелације имеђу пацификације и субверзије културних садржаја, на природу механизма комерцијализовања културних садржаја и њиховог апсорбовања од стране доминантне културе; осветљава се смисао активног и културно продуктивног деловања аутентичне личности на плану развоја и обогаћења субјекатске и објекатске позиције у култури. Такође, путем корелације традиционална култура:модерна култура осветљава се природа идентификације; указује се на резултате глобализације, на проблем квалитета комуникације, на културни улог институционализације садржина друштвене стварности; казује се о односу између економије и културе, осветљава се значај културних потреба и трансформације културних улога.
\end{abstract}

Кључне речи: идентитет, друштво, култура, културне потребе, књижевни отпор

Савремена проучавања културе полазе од становишта да култура представља целокупност духовних и материјалних производа који су настали кроз историјски процес као израз тежње за континуираним оплемењивањем људске природе. Према овом, промењеном начину сагледавања културе, садржина друштвених односа представља витални организам заједнички и перманентно оствариване производње и артикулације културних чинилаца, што иманентно одбацује и негира елитистички концепт одређења културе. Будући да је у данашње време неодрживо разумевање културе као уметничког израза активности само повлашћених група припадности, управо из разлога што се стваралачки потенцијал схвата не као привилегија изабраних већ као општељудско својство, и будући да између садржине друштвених односа и друштвеног уређења постоји тесно успостављена условља- 
вајућа веза заснована на систему регулације и интеракције, неопходно је анализу културног идентитета и културних феномена усмерити према осветљавању начина на који природа социо-културног комплекса одређује, детерминише и редефинише степен културне свести и активности појединца. Како „култура има изразито људску димензију у значењу које истиче личност и процес индивидуализације, али и друштвено обележје, кад наглашава друштвене реалности и тоталитет“ (Коковић 2000: 14), свако размишљање о природи културног деловања мора поћи од уважавања одређених поставки приступа и партикуларизма и холизма.

Социолошка литература посвећена истраживању проблема културног идентитета полази од сагледавања улоге појединца у сложеним социо-културним трансформацијама, те његове моћи да се идентитетски дефинише и препозна у континуитету промена као стабилна, целовита форма. Констелација: йојеgиначно или особено и

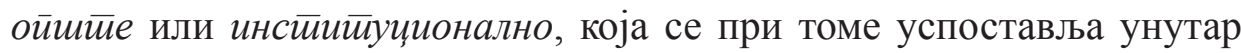
одређеног културног обрасца, показатељ је сложености природе комплементарних токова социјализације и културализације, њеног вредносног утицаја на оформљивање аутентичне личности и остваривање могућности деловања појединца на плану властитог и колективног културног развоја и унапређења. Култура је са друштвом повезана системима друштвених регулативних норми који имају задатак контроле и усмеравања културних токова и који, идеолошки, подразумевају позитиван развој културе. Међутим, дискрепанција која унутар вредносног система институционалних пракси може настати, међу осталом, институционализовањем или догматским вођењем норми или, пак, комерцијализовањем културних садржаја, иманентно провоцира субверзију у виду експанзије културних покрета и стилова који сведоче о непристајању на пацификацију културе. Сложеност природе социјализације и културализације, тако, произилази из парадоксалног и конфликтног односа који се гради услед истовремене омеђености културе системом друштвених регулативних правила и њене способности да превазиђе и надрасте утврђене институционалне норме. Култура овим процесима сведочи о развојним снагама друштва које се испољавају у континуираном вредновању и проверавању постојећих односа и утврђивању њихове одрживости у тренутним стањима со- 
цио-културних преображаја. Тек у континуираном проверавању одрживости вредносних критеријума у текућем времену, перципирањем, промишљањем и вредновањем социо-културног учинка материјалних и духовних производа индивидуалне и колективне активности, могу се стећи услови за оплемењивање и обогаћивање културе и савладавање дискрепанције.

Да бисмо потпуније осветлили смисао отпора у књижевности и култури, уопште, или начине на које личност постиже позитиван учинак на плану обогаћења културе, неопходно је најпре осветлити природу идентификације, указати на резултате глобализације, на проблем квалитета комуникације, указати на културни улог институционализације садржина друштвене стварности, те, у коначном, протумачити значај деловања аутентичне личности и значење културних потреба.

Управљена вредностима традиционалне културе у смисаоном координисању начина вођења и организовања живота, социјално и културно одређена нормама патријархалних вредности, личност се у пређашњим временима лакше идентитетски препознавала као целовита форма. Социолози су утврдили да се период у ком се стицало осећање зрелости и спремности личности да ступи у заједницу одраслих, као њен равноправан члан, поклапао са периодом заснивања породице. Снажно осећање смислене остварености живота представљало је, при томе, успешан завршетак једне од последњих егзистенцијално значајних иницијација појединца. Оно што карактерише традиционалне заједнице ,јесте непрестано понављање праксе која је остала иста као и саме заједнице“; та пракса, уведена давно, „омогућава супротстављање непромењеним проблемима или бар онима који се развијају врло споро [...]““ (Венсоно 2009: 79). Док у традиционалној култури социјализација прописује утврђене норме понашања сужавајући поље могућности испољавања поособљености индивидуе, у модерној култури социјализација бележи прелазак „са перцепције одрасле особе као испуњеног бића на перцепцију појединца у непрестаној (ре)конструкцији“ (Маршан 2009: 123-124). У модерним, индустријализованим савременим друштвима личност, тако, непрестано пролази кроз бројне и сложене идентификације жељеним или конфликтним интеграцијама у различите и променљиве групе припадности. Персонални идентитет тиме представља језгро перманентног (ре)дефинисања и (ре)организације чинилаца његове изградње. 
Друштвено-политички и економски условљен прелазак из традиционалне у модерну културу значио је, дакле, императив за континуираним вредновањем и преиспитавањем персоналног идентитета, умножавање могућности за идентитетску изградњу појединца у контексту једног или више културних образаца, културни плурализам као свеприсутну чињеницу од националног, политичког, економског и културног значаја, оформљивање и експанзију масовне културе и техничких медијума њене артикулације, бројност стилова живота, бујање тржишних понуда усмерених на задовољавање најразноврснијих људских потреба, масовно мигрирање становништва из села у градове и отуђење, као чињеницу поремећаја у сфери међуљудских духовних односа. Још неки од важних чинилаца промене представљају изражено комерцијализовање културних садржаја у сфери музике, књижевности, уметности, уопште, те моде, и њихове усмерености на пасивно и непродуктивно конзумерство и потрошњу уживаоца културе; потом, немогућност пријема и перцепције преобилних информација које се свакодневно човеку системима комуникацијских канала одашиљу; утисак свеповезаности цивилизација, настао услед техничког унапређења система међунационалног општења; усмереност човека на унапређење егзистенцијалних услова, мањак слободног времена и проблематизовање културне продуктивности његовог квалитета. Са друге стране, позитиван учинак који глобализација доноси јесте повећање броја технички писмених људи, бржа доступност и размена информација, повећа ње могућности мултикултуралне размене и обогаћивања садржаја друштвених односа. Посебно питање јесу трансформације у области језика или језичке иновације које представљају све распрострањеније уважавање и усвајање вокабулара интернационалног општења, не само у праксама посебних делатности већ и у свакодневном животу. У коначном, ваља нагласити и чињеницу да се квалитет комуникације у времену повећаног броја писмених људи, парадоксално, нарушава. Поремећај се јавља како у погледу слабљења духовног потенцијала језика, као медијума централизације људи, тако у сфери синтаксички пуног и исправног изражавања. Не само све приметније синтагматско изражавање већ и ограниченост времена у ком појединац може, или чак мора да искаже жељене садржаје, те питање учинка комуникације на примаоца 
поруке или мотивације примаоца да поруку прими што верније њеној копији, потом присуство комуникацијског шума, настало услед неприпадања пошиљаоца и примаоца поруке истом језичком или пак културном коду - све су то проблеми који у конкретним ситуацијама увеликом представљају сметњу у културно продуктивној размени садржаја подразумеване инструменталне комуникације.

„Културе укључују процес увек поновног уписивања и трансформације у којем се њихови различити и често међусобно супротстављени репертоари реафирмишу, модификују, извозе, доводе у питање и редефинишу“ а сам процес ,jе неизбежан зато што је својствен људима као активним бићима која уче и примењују културна значења и што је иманентан идеационој природи саме културе“ (Феј 2002: 77). Формирајући се у пољу одређеног културног обрасца у континуираним интеракцијама и валоризовањима норми објективне, институционално постулиране структуре и субјективне перцепције властитог сопства и његове активне артикулације, персонални идентитет прихвата, те модификује, структурира и исказује вредности и разноврсне моделе социо-културног општења, могућности (ре)организације и (ре)дефинисања политичке, економске, уметничке сфере друштвеног живота. Бројност и хетерогеност израза индивидуализираног и динамизованог културног односа према стварности друштвених садржаја потврда је постулираности различитости у идентитетском језгру друштвене и културне структуре човека, као бића које активно промишља и дела на плану унапређења и обогаћења властите мисли. То је и разлог због којег, дијахронијски и синхронијски посматрано, процес канонизовања одређених културних образаца провоцира субверзију као негирање социо-културне плодотворности спровођења праксе механичке производње готових (наметаних) културних решења и њихове ваљане, идеалне функционалне примене у свим доменима реализације индивидуалног и јавног социо-културног уређења.

Досадашња анализа показује да су личност и друштво антрополошки одређени, историјски условљени истовремено и сличностима, тежњом ка освајању целовитог, стабилног идентитета и именовањем културног сопства, и флуктуирајућим разликама које ниште сваку могућност коначног, апсолутног освајања хомогене структуре и које 
потврђују хијерархијску организованост друштва као историјски постулирану основу за његово функционисање.

Дате флуктуирајуће различитости у модернизованим, технолошки унапређеним друштвима данашњице представљају „квацас за глобализацијску експанзију“ постајући „плен естетског конзумирања“" (Лошонц 2012: 293). Феномен капиталистичког апсорбовања и пацификације културних садржаја препознаје се у различитим доменима манифестације социо-културног делања појединаца и друштава као парадоксална чињеница од изузетног значаја за осветљавање социолошке природе отпора уметничких и друштвених покрета и стилова.

Будући да циљ овог рада представља осветљавање феномена отпора у књижевности, указивање на природу корелацијски неразлучиве везе имеђу пацификације и субверзије културних садржаја, осветљавање механизма комерцијализовања културних садржаја и њиховог апсорбовања од стране доминантне културе, те начин и смисао активног и културно продуктивног деловања аутентичне личности на плану развоја и обогаћења субјекатске и објекатске позиције у култури, - нећемо се, овом приликом, задржавати на ближем описивању и одређењу конфликтног односа у простору друштвених покрета и организација.

\section{1. Отпор у књижевности?}

„Уколико књижевност није тек пуко бележење тока света или послеподневно улепшавање у стилу нагомилавања шарених ствари, или само резигнирано пролагођавање постојећем“, онда је постављање питање значаја отпора чак животни елемент књижевности (Лошонц 2013: 5).

Отпор у књижевности представља израз критичког преиспитивања и промишљања културног стања и стања у књижевном пољу; стваралачку активност као производ пропитивања, језичког и естетског одговарања на сублимирано искуство стварности уметности и живота. Историјски посматрано, књижевност отпора се формирала 
паралелно са снажним успостављањем самосвести личности и конституисала се као покушај чињења отклона према догматској књижевној субјективизацији и функционализацији литерарног израза, као покушај очувања његове културолошке вредности и као непристајање поособљене личности на каноне обавезног оријентисања и сврставања у владајуће стилске и генерацијске, или институционализоване моделе (Савић 2013: 65). Књижевност отпора представља аутентичне могућности књижевног оперисања у књижевном пољу, напор стваралачког духа да оплемени и унапреди позитиван развој културе.

Историјски реализована и друштвено-политички и економски условљена померања идејно и формално оствариваних поетичких кодова књижевности бележила су током XX века неколико препознатљивих периода у којима, са данашње дистанце, сагледавамо паралелно и повлашћивање естетском и социјалном укусу и отпор према дисциплиновању и хијерархизовању. Авангарда је, како бележи Алпар Лошонц, напорно „,радила на уздрмавању/разбијању пасивне удобности читалаца и прималаца уметничких дела“; она ,је покушавала да уприличава интервентност и да покида нити стварности [...]“ (Лошонц 2013: 5-9). Поједини њени пројекти, какав је дадизам, неминовно су морали окончати урушавањем у властитим напорима, будући да књижевност, друштвено условљена и у друштву поникла, није могла потврдити ништа друго до свој онтолошки и антрополошки карактер историјски конституисаног дискурса. Без обзира на краткотрајност и неодрживост појединих пројеката, бројност и богатство идејних и стилских књижевних решења у периоду авангарде сведочанство је стваралачког напора да се спољашња и унутрашња стварност човекова искаже на другачије начине него што се то чинило у непосредно претходећем књижевном периоду и у књижевној историји, уопште. Отпор који је авангардна књижевност пружила према слеђењу већ утабаних, постулираних путева стваралачког медијума значио је проширивање и продубљивање хоризонта људске мисли и изражајних могућности; не, дакле, само бунтовничку негацију или рушилаштво без конструктивних решења и могућности њихове стваралачке и културне оплодње. Допринос књижевности и култури оствариван је на 
различите и често, у стилском и жанровском погледу, експерименталне начине $^{1}$ који представљају важан простор за наредна испитивања и моделирања, од којих прозаизација поетског израза представља један од илустративних примера данашњице.

Књижевност отпора, дакле, полази од чињенице да друштво представља динамичан и отворен систем непрестаних идентификација и проширивања могућности за њихово настајање; да је оно организам чија се виталност и динамичност исказују у континуираности промена и у интеракцијским реализацијама тих промена. Из овога се може извести закључак да догматско вођење књижевног и културног отпора представља затварање отпора у негацију његове онтолошке димензије. У коначном, хијерархијско исходиште функционисања друштвених односа, омогућено идентитетским различитостима појединаца и друштава, културном отпору одређује природу непрестаног обнављања и трајања. Сам отпор у књижевности, као културни феномен, базиран је на парадоксу: инициран социо-културним трансформацијама друштва, отпор исказује своје вредносне координате као иновирани израз књижевности и супротставља их постојећим све док и оне, неприкосновеним механизмом наредних и континуираних социо-културних померања, не зазузму позицију медијума институционализације или пак комерцијализовања и не упишу се у линију апсорбираних производа који више квалитативно не одговарају на потребе човековог бића. Отпор у књижевности, тако, сведочи о перманентности захтева за континуираним оплемењивањем културне

1 Један од примера жанровског и језичког експериментисања представља кратак роман Љуgи іоворе Растка Петровића. Дато књижевно дело није остварено у духу класичног, традиционалног романа, нити се може жанровски означити као путопис; оно поседује извесне лирске елементе, а остварено је превасходно у дијалозима (нарочито први и други део романа). Идеја о јединствености живота и живљења уметнички се развија и постиже дезаутоматизацијом доживљаја стварности кроз језик. Петровић жели да оживотвори речи, да оне зазвуче као да су тек постале. Своју намеру успешно остварује промишљеним избором приповедачке технике, честим понављањем поздравних порука, непосредношћу говора, употребом ономатопејског језика и специфичном атмосфером коју изграђује. Без обзира на то што идеја о зайлушеностии изворног смисла речи, насталој услед свакодневне употребе лексичког репертоара, није изворно Петровићева, роман Љуgи іоворе представља уметнички успео пример авангардних тенденција. 
човекове природе, за непрестаним (само)трагалаштвом за оним књижевним и, уопште, културним могућностима које представљају потпуни, прецизнији израз проосећаности човека и датих времена. Са друге стране, он тиме указује на надрастајућу моћ културе у односу на домене могућности институционалне регулације културних чинилаца и токова.

Проблем који се у данашњем, модернизованом и технички унапређењом времену исказује као културно пацификована зона књижевних могућности јесте изражено комерцијализовање литерарних и, уопште, културних садржаја. Оно што Бурдије бележи и што се и данас чини релеватним јесте: „Произвођач вредности уметничког дела није уметник, него поље производње као свет веровања који производи вредност уметничког дела као фетиша, стварајући веровање у стваралачку моћ уметника“ (Бурдије 2003: 323). Отпор у књижевности, као рефлексиван однос према стварности уметности и као критичко проверавање постојећих односа и стања, управо је данас изузетно важан за књижевност, како она не би постала само део потрошачког добра. Квалитативно значајно књижевно дело не подражава стварност, не констатује је реалистички и само у виду забавне приче; оно прожима душом творца, сагледава егзистенцију и уписује себе у њу исказивајући уметнички оно невидљиво и чинећи га видљивим. Оно не пристаје на положај објекта културализације, као виgљивоі резултата искључиве мотивисаности економском добити, већ исказује самоосвешћеног субјекта културализације и делатника на плану позитивног развоја културе. Субјекат не пристаје на стратегије укрштања хетерогених социо-културних дискурса и изазова, на лака и брза решења, на пробављивост и потрошњу својих садржаја и њихову лаку заменљивост другима. Књижевност отпора не пристаје да буде у позицији ниїquне, између сећања и заборава: она се памти, она траје: она представља ваљан допринос идентитетском смислу времена и напор да оправда виши, хуманистички смисао свог постојања.

\section{2. Веза културе и економије}

Друштвене и културне појаве прожимају се у свакој људској делатности и творевини. Мада је култура израз живота - посебног 
друштвеног живота људи - њу ипак одређује непосредни материјални аспект друштвеног процеса, тј. постојећи друштвени односи и начин производње. (Коковић 2000: 63).

Начини на који се културни производ уписује у поље видљивости у материјализованом облику илустрација су међузависности коју успостављају економија и култура. Преласком из либералног у неолиберално време, обележеног израженијим обраћањима тржишту и тржишним могућностима, умножавањем канала, система и кодова за бржу и лакшу комуникацију пошиљаоца и примаоца поруке, материјализовани културни производи постају доступнији уживаоцу културе и широј јавности. Постепено превођење књижевних дела у електронске форме и њихово укључивање у планетарни систем циркулације увеликом је олакшало и убрзало успостављање комуникације међу културама. Међутим, у неолибералном времену пробилних информација, квалитативне разноликости културних производа, раста броја литературе редудантног и забавног карактера, маркирања и апсорбовања потрошачког капитала културног производа од стране естетизираног транснационалног тржишта, значај економског чиниоца у дистрибуирању културног производа све више иницира критичко (и проблематизовано) питање (не)видљивог односа између симболичког и економског капитала књижевног дела. Ако је искустиво комуникаиије искустиво кулииуре и ако је целина друштвено-културних појава детерминисана квалитетом комуникације (Коковић 2000: 44), онда књижевност, као културна чињеница и интегрални део комуникације, има своје значајно место у одређивању стања у позитивном развоју културе. Но, није само питање тривијализовања културних садржаја, рекламног дискурса представљања културног производа, те мотивације за његово пласирање једини изазов који се намеће култури; мањак слободног времена, те усмереност човека на потрошачко конзумерство, као израз потребе за забавом или, пак, као вид културно неосвешћеног значаја неопходности заузимања активније позиције у позитивном развоју културе, такође је проблем који захтева преиспитивање односа између стварних и конструисаних културних потреба. Управо се у литерарном пољу преиспитивања културно продуктивних књижевних могућности очитава културна потреба за успостављањем поремећене равнотеже, будући да механизам културног 
обогаћења друштва не може gа се своgи само на gавање и коришћење кулйуре (Џуверовић 1987: 29).

\section{2. Културне потребе и аутентична личност}

Култура даје животу место трајања, садржину и смисао бића, док му комуникација даје разлог постојања, повезујући га са светом споља и изнутра, са временом и простором, са прецима и потомцима (Јанићијевић 2000: 9).

Квалитет комуникације као организације, као свеповезујућег ткива временских категорија у проосећаном, доживљеном или, пак, акумулираном искуству језика, битно зависи од освешћености истинских културних потреба. Да би индивидуализирана личност унапредила своју субјекатску позицију у култури и рекцијски утицала на обогаћење културе, - што значи -, оплеменила и своју објекатску позицију у култури, неопходно је системом перципирања, анализе културне стварности ограничено властито слободно време активније усмерити ка оним активностима и пољима који доприносе квалитативном одговору на уложене напоре културног унапређења властите личности. Како бележи социолог Драган Коковић, „културне потребе постају значајне због своје снаге да створе аутентичну личност, да је одвоје од пасивно потрошачке егзистенције и вештачких потреба“, те, ако се истински негују, „културне потребе могу значити унапређење културе и културног богатства, представљати својеврсну брану од експанзије комерцијалног кича и шунда“" (Коковић 2000: 32).

Културне потребе одређује састав социо-културног идентитета личности, изграђиван у културном обрасцу најпре у оквиру примарне социјалне заједнице, потом у бројним и променљивим инеракцијама са различитим групама припадности. Природа и динамика културних трансформација кроз које индивидуализирана личност пролази зависе од разних фактора, егзистенцијалних, културних, друштвених, који у различитии мерама иницирају мотивацију као предуслов за аутентично, стваралачко културно делање. Институционално и/или ванинституционално изграђивање и усмеравање мишљења свакако је изузетно значајан чинилац у културној природи бирања и стицања група 
припадности и обликовању референтних група. У коначном, свакодневно медијско, једносмерно каналисање информација до појединца и маса, током ког личност комуницира са хетерогеним садржајима друштвене стварности обично на нивоу пасивног примања порука, дакле, углавном без комуникацијске могућности активнијег критичког, аналитичког учешћа, као и брзина смењивања информација, те немогућност да се њихова велика количина прими, те, временски, и резонује, - такође је, уз ограничено слободно време и ситуацију реалне освешћености културних потреба, значајан чинилац пацификације активног културног делања. Ипак, ваља нагласити да стварност модернизованог живота у одређеном тренутку нужно иницира културне реакције које се све израженије манифестују на различите начине: све приметнијом тежњом за повраћајем мање динамизованог живота, окретањем духовним и материјалним вредностима традиционалне културе, поновним појачаним интересовањем за религијске садржаје, покретањем културних активности или удруживањем у групе на основу кодова за заједничко идентитетско препознавање. Експанзија кодова за идентитетско окупљање и препознавање појединаца, те оформљивање група, стилова, удружења, покрета, показатељ је социо-културног отпора према слеђењу линије понуђених образаца доминантне културе. У књижевном пољу се ова хетерогеност манифестује експанзијом стилова, техника, могућности језичког поигравања са традиционалном конфигурацијом прозног или поетског стила, комбиновањем изражајних и формалних могућности жанрова, стилизираном и рефлексивном, визуелном или вербалном критичком комуникацијом са обрасцима и канонима садржине друштвене стварности, изгледом свакодневног, те медијског говора, природом трансмисије порука и шума дискурса. Овакво културно и уметничко окретање у традицији утемељеним или иновираним културним могућностима изражавања поособљене, аутентичне личности показатељ је освешћености потребе за активним промишљањем културне стварности и делањем на унапређењу и обогаћењу изражајних, комуникацијских, - духовних, и материјалних производа човековог рада. На пољу изграђеног и надограђујућег културног искуства и мотивација за јачањем субјекатске позиције у културализацији расте.

Културно позитиван процес трансформације културне улоге, 
напуштања конзумерског, потрошачког, те пасивизираног приступа и заузимања активне улоге ствараоца културе подразумева, дакле, самостално бирање извора порука у систему доступних порука, њихову стваралачку проосећаност и динамичко-рефлексивну и индивидуализирану исказаност. Тиме културна улога и моћ појединца у оплемењивању и обогаћивању садржина друштвене стварности јача. Књижевност отпора, као плод сублимираног искуства спољашњег и унутрашњег света, интеракцијског односа видљивог и невидљивог, као могуће поље за савладавање и превазилажење дискрепанције у култури, медијум је централизације аутентичних, истинских културних потреба. Ипак, парадоксалан однос пацификације и субверзије културних садражаја, као перманентно, - латентно или очигледно присутан социо-културни феномен, остаје и даље да служи као показатељ истинског стања у књижевности и култури, у систему обновљивих трансформација културних улога

\section{Литература}

Балибар 2002: Балибар, Етјен. Култура и идентитет. У: Кнежевић, Зоран (ур.). Нација, кулйура и ірађанстиво. Београд. С. 47-66.

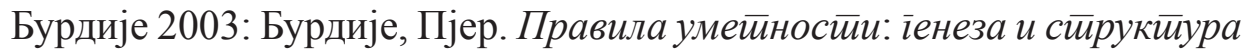
йоља киижевносиич. Нови Сад.

Венсоно 2009: Венсоно, Женевјев. Социјализација и идентитет. У: Ха-

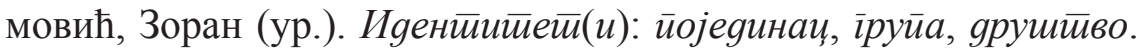
Београд. С. 77-81.

Зимел 2005: Зимел, Георг. Велики градови и духовни живот. У: Јовановић, Небојша (ур.). Урбана соичолойија. Београд. С. 69-77.

Јанићијевић 2000: Јанићијевић, Јасна. Комуникацчија и кулйура. Нови Сад.

Коковић 2000: Коковић, Драган. Куличура и умешиносй. Нови Сад.

Камијери 2009: Камијери, Кармел. Културе и стратегије, или хиљаду

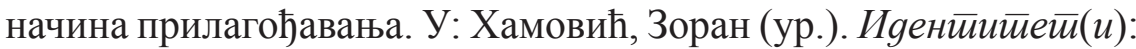
йојеgинаи, іруйа, gрушӣво. Београд. С. 105-112.

Кимлика 2002: Кимлика, Вил. Слобода и култура. У: Кнежевић, Зоран (ур.). Нација, кулйура и ірађансииво. Београд. С. 131-165. 
Ле Бретон 2009: Ле Бретон, Давид. Тетоваже и пирсинг... идентитет-

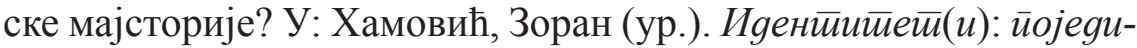
наи, іруйа, друшииво. Београд. С. 132-141.

Леконт 2009: Леконт, Жак. Означити своју различитост. Разговор са

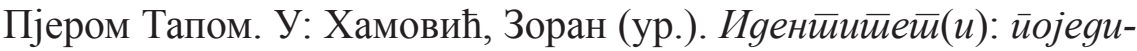
наи, ірруйа, ярушииво. Београд. С. 72-76.

Лелуш 2009: Лелуш, Серж. Појединац и модерно друштво. Разговор

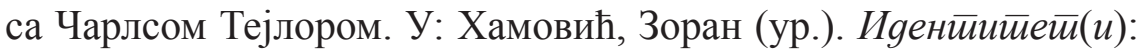
йојеgинаи, іруйа, друшитво. Београд. С. 113-122.

Лошонц 2012: Лошонц, Алпар. Да ли идентитетски обрасци пред-

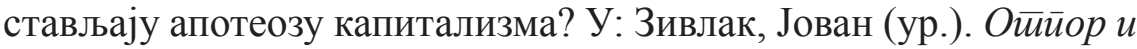
моћ. Нови Сад. С. 278-339.

Лошонц 2013: Лошонц, Алпар. Кюижевносии као ирекияање йока свейа. У: Зивлак, Јован (ур.). Злайна ірреgа. Број 143/144. Година XIII, септембар/октобар 2013. Нови Сад. С. 5-11.

Марк 2009: Марк, Едмонд. Идентитетска изградња појединца. У: Ха-

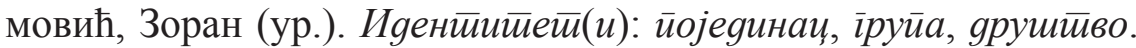
Београд. С. 41-50.

Мартино 2009: Мартино, Делфина. JА у социјалној психологији. У:

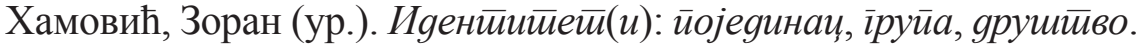
Београд. С. 51-60.

Маршан 2009: Маршан, Жил. Тражење себе, пут крста? У: Хамовић,

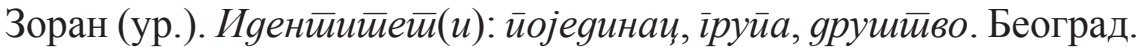
C. $123-131$.

Оберле 2009: Оберле, Доминик. Живети заједно. Група у друштвеној

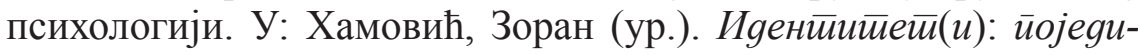
наи, іруйа, ярушииво. Београд. С. 145-158.

Рансијер 2008: Рансијер, Жак. Полийика књижевностии. Нови Сад. Руано-Борбалан 2009: Руано-Борбалан, Жан-Клод. Изградња иден-

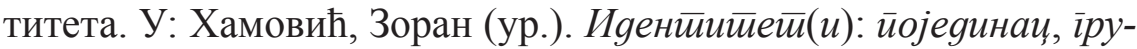
йa, gрушииво. Београд. С. 5-16.

Савић 2013: Савић, Маја. У йросйору књижевной йоља књижевних могуућносии. У: Зивлак, Јован (ур.). Злайна ірреgа. Број 143/144. Година XIII, септембар/октобар 2013. Нови Сад. С. 64-72.

Феј 2002: Феј, Брајан. Да ли нас наша култура или друштво чине оним што јесмо. У: Кнежевић, Зоран (ур.). Нащија, куличура и ірађансииво. Београд. С. 67-86. 
Џуверовић 1987: Џуверовић, Борисав. Сйорне кулимуре. Београд. Халперн 2009: Халперн, Катрин. Треба ли престати да се говори о

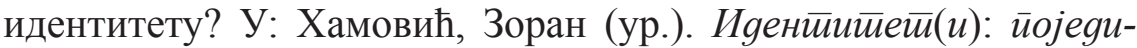
наи, їруйа, ярушииво. Београд. С. 17-27.

Шовије 2009: Шовије, Стефан. Филозофско питање личног иденти-

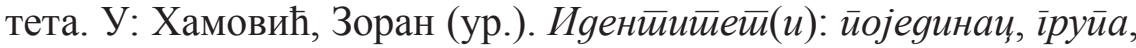
ярушииво. Београд. С. 31-40.

\author{
Maja Savić
}

\title{
Summary
}

\section{LITERARY RESISTANCE AS A CULTURAL PHENOMENON}

The paper deals with the phenomenon of resistance in literature and reflects on the ambiguous nature of correlation between pacification and subversion of cultural elements, as well as on the nature of commercialization mechanisms for cultural contents and the way in which dominant culture absorbs those contents. Secondly, it analyzes the meaning of active and culturally productive engagement of an authentic individual, with regard to the development and enrichment of the subject and object positions within the realms of culture. Thirdly, using the traditional culture - modern culture correlation, the paper discusses the nature of identification; it also shows the results of globalization, the issue of the quality of communication, and the cultural share in institutionalizing the contents of social reality. Lastly, the paper examines the relationship between economy and culture, the importance of cultural demands and the transformation of cultural roles.

Key words: identity, society, culture, cultural demands, literary resistance 